\title{
Effect of Sowing Dates on Physiological Parameters, Productivity and Economical Gain of Different Rice Varieties under Rainfed Condition
}

\author{
Punit Tiwari*, R.K. Tiwari, Jyoti Tiwari and Vaishali Yadav \\ Department of Agronomy, JNKVV, College of Agriculture, Rewa-486001, \\ Madhya Pradesh, India \\ *Corresponding author
}

\section{A B S T R A C T}

A field experiment was conducted in Kharif season of 2014 at, J.N.K.V.V. College of Agriculture, Instructional Farm, Rewa (M.P.) under All India Coordinated Rice

Keywords

Rice, Physiological parameters, Rainfed condition

Article Info

Accepted:

20 January 2018

Available Online:

10 February 2018 Improvement Project to study the "effect of sowing dates on performance of different rice varieties under upland condition". Objective of this experiment was to find out the effect of sowing dates on physiological parameters and productivity of different rice varieties, suitable rice varieties under upland condition. The experiment was laid out in split-plot design with four replications. The treatments comprised of three sowing dates $\left(3^{\text {rd }} \mathrm{July}, 8^{\text {th }}\right.$ July and $13^{\text {th }}$ July) in main plots and 5 varieties (Danteshwari, Vandana, IR-64, PS-3 and PS-5) in sub plots. The varieties were sown by direct-seeding on $3^{\text {rd }}, 8^{\text {th }}$ and $13^{\text {th }} \mathrm{July}$. The crops were grown under recommended package of practices. Among the varieties, PS-3 and then PS-5 resulted in maximum physiological parameters and grain yield up to 40.90 to $43.27 \mathrm{q} / \mathrm{ha}$. The most optimum date of sowing of rainfed rice was $3^{\text {rd }}$ July which gave maximum physiological parameters, grain yield upto $38.54 \mathrm{q} / \mathrm{ha}$ and economic return. Thus, variety PS-3 or PS-5 grown on $3^{\text {rd }}$ July was suitable to obtain maximum productivity from rice under rainfed conditions of this region.

\section{Introduction}

Rice is the most important staple food crop of India. The importance of rice in Asia is more pronounced as rice typically accounts $32 \%$ of cropped area in Asia. India is next to China in rice production.

In India, rice is grown in an area of 44.6 million hectare with a production of 109.5 million tones and average productivity of 2.62 tons per hectare. The slogan "Rice is life" is most appropriate for India as this crop plays a vital role in our national food security and is a means of livelihood for millions of rural households. Projection of India's rice production target for $2025 \mathrm{AD}$ is 140 million tones which can be achieved only by increasing rice production by 2 million tons per year over the existing in the coming decade (Sridhar et al., 2011). In M.P. total area under rice production is 1.7 million ha in which only 223 thousands ha comes under irrigated situation. Total rice production is 1710 thousand tones in which 1313 thousand tones is from rained and 397 thousand tones is 
from irrigated area. The productivity of total rice area in M.P. is $1103 \mathrm{~kg} / \mathrm{ha}$ while irrigated area has $1273 \mathrm{~kg} / \mathrm{ha}$.

Direct-seeding of rice under unpuddled conditions as appears to be the most credible option and efficient irrigation water technology apart from its cost and labor effectiveness. Expansion in the irrigated area, introduction of early maturing rice cultivars, availability of selective herbicides for weed management together with increasing transplanting cost and declining profitability of transplanted rice production system have encouraged rice farmers to shift from transplanting to direct-seeding (Subbaiah et al., 1999). Planting time is the major factor that determines the productivity of a crop. Optimum planting time for a crop is location specific. Optimum planting time worked out June 1-10 in Punjab (Gill et al., 2006), June 15 at New Delhi (Narayanaswamy et al., 1982) and June 5-15 at Cuttack (Chandra et al., 1991). Early or delay in sowing leads to lower production of direct seeded rice. Optimum sowing time thus needs to be standardized for every ago-ecological situation for success of direct seeded rice. Gravois and Helms (1998) also showed that rice grain yields declined as seeding date was delayed. Early sown crops, despite poor germination, performed well due to better establishment and tiller production before water rose to higher depths in the field (Sharma, 1994). Timely sowing of rice results in earlier harvest and allows timely planting of the next wheat or other crops. The rice-wheat system productivity was nearly 12 tons per hectare when about 25 days old rice seedlings were transplanted before end of June. The total system productivity is reduced by more than 40 per cent when field were planted after 15 August (Rai, 2006). Timely sowing of rice crop is also found to increase the rain water use efficiency as compared to the delayed planting. The exact sowing date for directseeding of rice also plays a vital role in improving its growth and increasing the yield. The sowing time of the rice crop is important for three major reasons. Firstly, it ensures that vegetative growth occurs during a period of satisfactory temperatures and high levels of solar radiation. Secondly, the optimum sowing time for each cultivar ensures the cold sensitive stage occurs when the minimum night temperatures are historically the warmest. Thirdly, sowing on time guarantees that grain filling occurs when milder autumn temperatures are more likely, hence good grain quality is achieved (Farrell et al., 2003). Sowing date also has a direct impact on the rate of establishment of rice seedling (Tashiro et al., 1999). Early date of sowing is the best time of sowing for important properties such as maximum tillering, panicle initiation, chlorophyll content, leaf area index, sink capacity, panicle length, number of panicles $\mathrm{m}^{-2}$, and grain yield (Khalifa, 2009). Delay in planting from 15 June to 15 July decreased leaf area index (10\%) (Rai and Kushwaha, 2008). At a specific location, maximum grain yield can be achieved by planting the crop at the optimum time, which may vary from variety to variety (Reddy and Narayana, 1984). Early transplanting dates increase the physiological parameter and grain of rice as compared to late planting (Mukesh et al., 2008).

\section{Materials and Methods}

The field experiment was conducted at College of Agriculture, Instructional Farm, Rewa (M.P.) under All India Coordinated Rice Improvement Project in Kharif season of 2014. The field was well leveled before laying out the experiment. The soil of the experimental field has been grouped under sandy clay loam with homogeneity in fertility. It was just below neutral in reaction $(\mathrm{pH} 6.5)$ with normal electrical conductivity $(0.42$ $\mathrm{dS} / \mathrm{m})$. The organic carbon content $(0.56 \%$ $0.60 \%)$ and available nitrogen $(294.0-337 \mathrm{~kg}$ /ha) were both medium. The available 
phosphorus (18.0-36.0 $\mathrm{kg} / \mathrm{ha})$ and potash (314-611 kg /ha) were medium and high, respectively. The soil $\mathrm{pH}$ was (6.5) normal. Electrical conductivity $(0.42 \mathrm{dS} / \mathrm{m})$ of soil was found normal. The experiment was laid out in split-plot design with four replications. The treatments comprised of three sowing dates $\left(3^{\text {rd }}\right.$ July, $8^{\text {th }}$ July and $13^{\text {th }}$ July) in main plots and 5 varieties (Danteshwari, Vandana, IR 64, PS-3 and PS-5) in sub plots. The varieties were sown by direct seeding on $3^{\text {rd }}$, $8^{\text {th }}$ and $13^{\text {th }}$ July. Nitrogen, phosphorus, potassium, and zinc were applied at 100:60:40 $\mathrm{kg}$ of $\mathrm{N}$ : P: K/ha respectively in each plot in the form of urea, single super phosphate and muriate of potash. Full dose of phosphorus and potassium were applied basal in all the treatments. Half dose of nitrogen was applied on standing crop at two weeks after sowing by top dressing. Remaining half nitrogen was applied in two equal splits at 45 DAS and panicle initiation stages. Seed of rice were sown on July $3^{\text {rd }}$, July $8^{\text {th }}$ and July $13^{\text {th }} 2014$ by direct seeded in lines $20 \mathrm{~cm}$ apart keeping a seed rate of $30 \mathrm{~kg} / \mathrm{ha}$. The seeds were treated with bavistin @ 2g/kg seed before sowing. Various observations were recorded periodically in relation to growth and yield attributing characters and finally, economics of the treatments was calculated.

\section{Results and Discussion}

\section{Physiological parameters}

The morphological growth observations recorded periodically had exhibited many interesting architectural variations due to variation in sowing dates and varieties grown. The leaves /plant, length and width of leaf and leaf area index were, in general, increased steadily or by multifold in all the treatments with the successive growth and development stages i.e. from 30 DAS to 90 DAS or up to harvest stage. These physiological parameters were, in general, enhanced very fast between
30 to 60 DAS; thereafter the rise was normally slow up to 90 DAS or harvest stage. Thus up to the harvest stage, leaves ranged from 41.62 to $52.95 /$ plant, leaf length 34.83 to $39.85 \mathrm{~cm}$, leaf width 1.16 to $1.33 \mathrm{~cm}$ and leaf area index 4.37 to 5.31 under the various treatments (Table 1). In fact, the variable trend and limit of vegetative growth during successive growth stages, before the start of reproductive phase is mainly governed by the genetic behavior inherited in the high yielding rice genotypes as well as the crop management practices and by the existing agro-climatic conditions of the region. As regards with the effect of different sowing dates, earliest $3^{\text {rd }}$ July sowing produced significantly higher growth characters as compared to the sowing of crop on the later dates. The no. of leaves was 48.39/plant, leaf length $37.57 \mathrm{~cm}$, leaf width $1.30 \mathrm{~cm}$ and LAI 4.94. On the other hand, $13^{\text {th }}$ July sowing date reduced all these parameters almost up to significant extent i.e. 46.84 leaves/plant, $35.61 \mathrm{~cm}$ leaf length, $1.19 \mathrm{~cm}$ leaf with and 4.57 LAI. In fact, there is a vital role of time of planting in paddy crop because of the variation in the duration, photosensitiveness, thermo-sensitiveness and vegetative lag period of the variety. A variety of short duration may suit better from early planting to late planting because of the fact that such varieties complete their life cycle with in short period with less effect of photoperiod and temperature. The longer duration photo and thermo sensitive varieties may not be perform better under late planting condition while varieties photo and thermoinsensitive may perform better under normal to late planting condition with limited effect on yield of crop. The variation in the above mentioned physiological parameters have also been reported by many research workers (Manjappa and Kumar, 2002; Vange and obi, 2006; Sreenivas et al., 2007; Rai and Kushwaha, 2008; Khalifa, 2009; Kerketta et al., 2010; Singh et al., 2012 and Limochi and Eskandari; 2013). 
Table.1 Physiological parameters of rainfed rice as influenced by dates of sowing and varieties

\begin{tabular}{|c|c|c|c|c|c|c|c|c|c|c|c|c|}
\hline \multirow[t]{2}{*}{ Treatments } & \multicolumn{3}{|c|}{ Number of leaves/plant } & \multicolumn{3}{|c|}{ Leaf length (cm) } & \multicolumn{3}{|c|}{ leaf width $(\mathrm{cm})$} & \multicolumn{3}{|c|}{ Leaf area index } \\
\hline & 30 DAS & $\begin{array}{c}60 \\
\text { DASS }\end{array}$ & $\begin{array}{c}90 \\
\text { DAS }\end{array}$ & $\begin{array}{c}30 \\
\text { DAS }\end{array}$ & $\begin{array}{c}60 \\
\text { DAS }\end{array}$ & $\begin{array}{c}90 \\
\text { DAS }\end{array}$ & $\begin{array}{c}30 \\
\text { DAS }\end{array}$ & $\begin{array}{c}60 \\
\text { DAS }\end{array}$ & $\begin{array}{c}90 \\
\text { DAS }\end{array}$ & $\begin{array}{c}30 \\
\text { DAS }\end{array}$ & $\begin{array}{c}60 \\
\text { DAS }\end{array}$ & 90 DAS \\
\hline$\frac{\text { Dates of }}{\frac{\text { sowing: }}{3^{\text {rd }}}}$ & 530 & 4446 & 4830 & 1018 & 2060 & 3757 & 055 & 100 & 130 & 02 & 247 & 404 \\
\hline $8^{\text {th }}$ July & 5.12 & 43.97 & 47.72 & 19.59 & 29.43 & 36.99 & 0.52 & $\begin{array}{l}1.09 \\
1.03\end{array}$ & $\begin{array}{l}1.50 \\
1.21\end{array}$ & 0.19 & 3.41 & $\begin{array}{l}4.94 \\
4.83\end{array}$ \\
\hline $13^{\text {th }}$ July & 4.84 & 43.26 & 46.84 & 18.70 & 28.88 & 35.61 & 0.50 & 1.00 & 1.19 & 0.18 & 2.94 & 4.57 \\
\hline S.Em+ & 0.64 & 0.37 & 0.68 & 0.18 & 0.18 & 0.38 & 0.01 & 0.02 & 0.02 & 0.003 & 0.006 & 0.021 \\
\hline C.D. @ 5\% & 0.22 & NS & NS & 0.62 & 0.63 & 1.33 & 0.03 & 0.05 & 0.07 & 0.010 & 0.022 & 0.075 \\
\hline Varieties: & & & & & & & & & & & & \\
\hline Danteshwari & 4.58 & 41.14 & 44.08 & 18.98 & 30.50 & 36.79 & 0.55 & 1.09 & 1.27 & 0.19 & 3.00 & 4.52 \\
\hline Vandana & 4.43 & 39.24 & 41.62 & 22.16 & 31.64 & 39.85 & 0.55 & 1.10 & 1.33 & 0.16 & 2.86 & 4.37 \\
\hline IR-64 & 5.04 & 45.01 & 48.01 & 18.92 & 29.41 & 36.60 & 0.53 & 0.99 & 1.21 & 0.20 & 3.24 & 4.64 \\
\hline PS-3 & 5.81 & 48.51 & 51.60 & 18.65 & 27.22 & 35.53 & 0.53 & 0.96 & 1.16 & 0.22 & 3.65 & 5.31 \\
\hline PS-5 & 5.59 & 45.60 & 52.95 & 17.07 & 27.89 & 34.83 & 0.47 & 1.05 & 1.20 & 0.20 & 3.48 & 5.06 \\
\hline S.Em \pm & 0.14 & 0.49 & 0.55 & 0.24 & 0.23 & 0.45 & 0.01 & 0.01 & 0.01 & 0.004 & 0.013 & 0.028 \\
\hline C.D. @ 5\% & 0.41 & 1.40 & 1.56 & 0.69 & 0.67 & 1.28 & 0.03 & 0.04 & 0.05 & 0.012 & 0.040 & 0.080 \\
\hline Interaction & NS & NS & NS & NS & Sig. & Sig. & NS & Sig. & Sig. & NS & Sig. & Sig. \\
\hline
\end{tabular}

Table.2 Productivity and economical gain of rainfed rice as influenced by Dates of sowing and varieties

\begin{tabular}{|c|c|c|c|}
\hline $\begin{array}{c}\text { Treatments } \\
\text { Dates of sowing : }\end{array}$ & Grain yield (q/ha) & Straw yield (q/ha) & Net income (Rs./ha) \\
\hline $3^{\text {rd }}$ July & & & \\
\hline $8^{\text {th }}$ July & 38.54 & 88.86 & 41446 \\
\hline 13 $^{\text {th }}$ July & 37.52 & 87.65 & 40379 \\
\hline S.Em+ & 36.32 & 84.27 & 38024 \\
\hline C.D. @ 5\% & 0.17 & 0.46 & - \\
\hline Varieties: & $\mathbf{0 . 5 8}$ & $\mathbf{1 . 5 9}$ & - \\
\hline Danteshwari & 36.29 & & 36330 \\
\hline Vandana & 28.96 & 67.18 & 25504 \\
\hline IR-64 & 38.38 & 58.53 & 39485 \\
\hline PS-3 & 43.27 & 70.42 & 49778 \\
\hline PS-5 & 40.90 & 108.84 & 48652 \\
\hline S.Em+ & 0.48 & 129.66 & - \\
\hline C.D. @ 5\% & $\mathbf{1 . 3 8}$ & 1.75 & - \\
\hline Interaction & $\mathbf{N S}$ & $\mathbf{5 . 0 1}$ & - \\
\hline & & $\mathbf{N S}$ & \\
\hline
\end{tabular}

Amongst the varieties, PS-3 resulted in significantly higher leaf area index (5.31), Vandana recorded significantly higher plant leaf length $(39.85 \mathrm{~cm})$ and leaf width $(1.33$ $\mathrm{cm})$. The other characters viz. leaves (41.62/plant) and leaf area index (4.37) were found significantly lower in case of Vandana. The other varieties also showed significant differences in all the growth characters under observation. Such type of variation in physiological parameters among the different varieties might be owing to differences in their parental origin which caused variation in their genetically inheritance for such traits. In fact rice varieties very in their seedling vigor, drought tolerance, maturity duration and 
differences in the resource utilization and productivity. The present funding corroborate with those of several researches (Ahn et al., 2000; Balaswamy and Kulkarni, 2001; Reddy, 2002; Norman et al., 2003, Mukesh et al., 2008; Nawlakhe et al., 2009, and Walia et al., 2014).

\section{Productivity parameters}

Grain yield (38.54 q/ha) and straw yield $(88.86 \mathrm{q} / \mathrm{ha})$ was maximum in case of earliest $3^{\text {rd }}$ July sowing date. The significantly lowest grain yield (36.32 q/ha) and straw yield $(84.27 \mathrm{q} / \mathrm{ha})$ was noted in case of late sowing date of $13^{\text {th }}$ July under rainfed conditions. The productivity parameters were found exactly in accordance with the physiological parameters under these sowing dates. The yield reductions might be due to reduction in vegetative growth period on account of delayed sowing. The yield reductions under later sowing dates have been reported by Giri et al., (2001), Manjappa and Kumar (2002), Vange and Obi (2006), Sreenivash et al., (2007), Rai and Kushwaha (2008), Safdar et al., (2008), Hussain et al., (2009), Khalifa (2009), Kerkatta et al., (2010), Singh et al., (2012), Limochi and Eskandari (2013).

The variety PS-3 produced highest grain (43.27 q/ha) but lower straw (108.84 q/ha). However, the reverse was true in case of PS-5 variety of rice. The grain yield was lower (40.90 q/ha) and straw yield was highest (127.66 q/ha). Significantly lowest grain yield (28.96 q/ha) and straw yield (58.53 q/ha) was recorded from Vandana variety. The variety IR-64 attained the third position with the productivity parameters. All these parameters were found exactly in accordance with physiological parameters responsible for such a deviation (Table 2). The present results are in accordance with those of Saroch and Thakur (2000), Reedy (2002), Nayak et al., (2003), Narman et al., (2003), Arumugam et al., (2007), Mukesh et al., (2008), Gill et al., (2009), Nawlakha et al., (2009), Suresh et al., (2013) and Walia et al., (2014).

\section{Economical gain}

The timely sowing practice with suitable crop variety involves no any extra expenditure but gives acceptable yield and net income. Late sowing adversely influence the yield and thereby net income. In this research, $3^{\text {rd }}$ July of upland rice proved most beneficial giving maximum net income up to Rs. 41446/ha. The crop sown five days late on $8^{\text {th }}$ July reduced the net income by Rs. 1067/ha then when sown ten days late on $13^{\text {th }}$ July, the net income reduced up to Rs. 3422/ha.

In case of rice varieties, PS-3 proved its superiority by giving highest net income up to Rs. 49778/ha. However the second equally best variety was PS-5 giving net income up to Rs. 48652/ha. The third best variety was IR64 nearby giving net income up to Rs. 39485/ha. This was followed by Danteshwari and then Vandana giving lowest net income up to Rs. 25504/ha which reduced by Rs. $24274 /$ ha. The net income in related to the crop productivity and the gross income received. The variations in economic gain due to different varieties have also been reported by many researches as mentioned earlier.

\section{References}

Ahn D, Choi JS, Choi CD, Lee SP Choi BS and Lee SC. 2000. Effects of seeding dates for direct seeding on dry paddy on growth and yield of rice varieties in Youngnam region. Korean Journal of Crop Science. 45(3): 185-189.

Anonymous. 2014. Annual report. Department of Agriculture and Cooperation Ministry of Agriculture Government of India.

Arumugam M, Rajanna MP and 
Vidyachandra B. 2007. Stability of rice genotypes for yield and yield components over extended dates of sowing under Cauvery command area in Karnataka. Oryza- An International Journal on Rice. 44(2):104-107.

Balaswamy K and Kulkarni N. 2001. Influence of time of transplanting on the performance of certain scented rice varieties in Andhra Pradesh. Journal of research ANGRAU. 29(2/3):98-101.

Chandra D, Moorthy BTS, Jha KP and Manna GB. 1991. Agronomic practices for augmenting rice (Oryza sativa) production in rained rainfed ecosystem of Orissa. Indian Journal of Agronomy. 36:313-21.

Farrell TC, Fox K, Williams RL, Fukai S and Lewin LG. 2003. Avoiding low temperature damage in Australia's rice industry with photoperiod sensitive cultivars. Proceedings of the 11th Australian Agronomy Conference. Deakin University, Geelong (Feb. 2-6), Victoria, Australia.

Gill MS, Gill JS and Gill GK. 2009. Effect of time of transplanting on performance of different Basmati rice (Oryza sativa L.) cultivars. Environment and Ecology. 27(4A):1757-1759.

Gill MS, Kumar A and Kumar P. 2006. Growth and yield of rice (Oryza sativa) cultivars under various methods and time of sowing. Indian Journal of Agronomy. 51:123-27.

Gravois KA and Helms RS. 1996. Seeding rate effect on rough rice yield, head rice and total milled rice. Agronomy Journal. 88:82-84.

Kerketta NK, Dwivedi SK, Shrivastava GK and Saxena RR. 2010. Rooting pattern and yield of rice under rained upland situation in Alfisol with different sowing dates and $\mathrm{P}$ and $\mathrm{K}$ levels. Current Advances in Agricultural Sciences. 2(2):115 117.
Khalifa AABA 2009. Physiological evaluation of some hybrid rice varieties under different sowing dates. Australian Journal of Crop Science 3(3): 178-183.

Limochi K and Eskandari H. 2013. Effect of planting date on performance of flag leaf stomata and grain yield of rice cultivar. International Journal of Agronomy and Plant Production 4(4): 769-773.

Manjappa K and Kumar P. 2002. Performance of rained transplanted rice under different dates of planting in hilly zone of Karnataka. Karnataka Journal of Agricultural Sciences. 15(1):136-138.

Mukesh, Singh I, Pannu RK, Prasad D and Ram A. 2009. Effects of different transplanting dates on yield and quality of basmati rice (Oryza sativa) varieties. Chaudhary Charan Singh Haryana Agricultural University, Hisar.

Narayanaswamy S, Yoogeshwar RY, Ramsheshaiash K and Sivasankaan RV. 1982. Effect of time and method of sowing rice varieties in puddled soil during wet season. Oryza. 19:47-52.

Nawlakhe SM. Mankar DD, and Jiotode DJ. 2009. Performance of basmati type scented rice (Oryza sativa L.) cultivars under different dates of transplanting eastern Vidarbha. Crop Research (Hisar). 37(1/3):158-160.

Nayak BC, Dalei BB and Chodhury BK. 2003. Response of hybrid rice to date of planting, spacing and seedling rate during wet season. Indian Journal of Agronomy. 48 (3):172-174.

Norman RJ, Wilson CE, Boothe DL and Slaton NA. 2003. Grain yield performance of rice cultivars grown in Northeast Arkansas as influenced by seeding date. Research Series-Arkansas Agricultural Experiment Station. (504): 288-291.

Rai HK and Kushwaha HS. 2008. Effect of planting dates and soil water regimes on 
growth and Yield of upland rice. Oryza - An International Journal on Rice. 45(2):129-132.

Rai HK and Kushwaha HS. 2008. Effect of planting dates and soil water regimes on growth and Yield of upland rice. Oryza - An International Journal on Rice. 45(2):129-132.

Reddy SN and Narayana P.1984. Pattern of dry matter accumulation and $\mathrm{N}$ uptake by rice as influenced by age of seedling and date of planting. Andhra Agriculture Journal. 32: 155-56.

Reedy CS. 2002.Performance of rice (Oryza sativa) varieties under different times of planting. Indian Journal of Agronomy. 47(2):199-202.

Saroch K and Thakur RC. 2000. Rained rice cultivation as influenced by varieties, weed management and sowing dates. Advances in Agricultural Research in India. 14:121-127.

Sharma AR. 1994. Effect of different methods and timings of stand establishme on performance of rained lowland rice under $0-50 \mathrm{~cm}$ water depth. Journal of Agronomy and Crop Science. 172(1):38-51.

Singh AK, Chandra N and Bharti RC. 2012. Effects of genotype and planting time on phonology and performance of rice (Oryza sativa L.). Vegetos, 25(1):151156.

Sridhar CJ, Ramchandappa BK, Nanjappa HV and Mavarkar NS. 2011. Effect of genotypes, planting geometry and method of establishment on growth and yield of aerobic rice. Mysore journal of Agriculture Science. 45(3):501-505.

Subbiah SV, Singh SP, Kumar RM and Padmaja K.1999. Drum seeding technology as a substitute for transplanting in India. IRRE CREMNET Workshop cum Group Meeting, 24-27 August. SWMRI. Thanjavur, Tamilnadu.

Suresh K, Balaguravalah D, Ramalu V and Rao CSH. 2013. Evaluation of rice varieties under different management practices for late planting situation of Nagarjune Sagar left canal command area Andhra Pradesh, India. International Journal of Plant Animal and environmental Science 3(2): 258260.

Tashiro T, Saigusa M and Shibuya K. 1999. A Trial of No-tillage Direct Seeding of Rice (Oryza sativa L.) at Early Spring in Cold Climate Region in Japan. Japanese Journal of Crop Science 68(1):146-150.

Walia US, Walia SS, Sindhu and Nayyar S. 2014. Production of direct-seeded rice in relation to different dates of sowing and varieties in central Punjab. Journal of crop weed.10(1): 126-129

\section{How to cite this article:}

Punit Tiwari, R.K. Tiwari, Jyoti Tiwari and Vaishali Yadav. 2018. Effect of Sowing Dates on Physiological Parameters, Productivity and Economical Gain of Different Rice Varieties under Rainfed Condition. Int.J.Curr.Microbiol.App.Sci. 7(02): 2451-2457. doi: https://doi.org/10.20546/ijcmas.2018.702.298 